\title{
Amylase addition increases starch ruminal digestion in first-lactation cows fed high and low starch diets
}

\author{
P. Nozière, ${ }^{*} \dagger^{1}$ W. Steinberg, $\neq$ M. Silberberg, ${ }^{*} \dagger$ and D. P. Morgavi ${ }^{\star} \dagger$ \\ *INRA, UMR1213 Herbivores, F-63122 Saint-Genès-Champanelle, France \\ †Clermont Université, VetAgro Sup, UMR Herbivores, BP 10448, F-63000 Clermont-Ferrand, France \\ fDSM Nutritional Products, CH 4002 Basel, Switzerland
}

\section{ABSTRACT}

The objective of this study was to evaluate the effect of an exogenous amylase preparation on digestion of low- and high-starch diets in dairy cattle. Rumen and total-tract nutrient digestibility were measured in a 4 $\times 4$ Latin square design with 28 -d periods using 4 firstlactation cows cannulated at the rumen and duodenum. Corn silage-based diets had 20 or $30 \%$ starch, attained by changing the composition of concentrate, with or without addition of an exogenous amylase preparation. Effects of the enzyme additive were observed on ruminal digestibility but not at the total-tract level. Ruminal digestibility of starch increased from $75 \%$ in control to $81 \%$ with amylase supplementation. This difference in ruminal starch digestion was compensated postruminally, so that the total-tract digestibility of starch was almost complete and did not differ between treatments. The amylase supplement also increased the true ruminal digestibility of organic matter but did not affect microbial $\mathrm{N}$ flow to the duodenum. Amylase supplement reduced the proportion of acetate and butyrate and increased that of propionate, particularly in the high-starch diet, where it tended to increase the concentration of total volatile fatty acids in the rumen. Other effects were a higher amylase activity in the solid-associated microbial community and a tendency for lower numbers of protozoa. In contrast, we observed no changes in intake, production, dry matter and fiber (neutral detergent fiber and acid detergent fiber) digestibility, or ruminal digestion, and no or small changes on selected fibrolytic and amylolytic bacteria and on the microbial community in general. We conclude that the exogenous amylase improved starch digestion in the rumen in first-lactation cows with moderate intake and production levels.

Key words: amylase, ruminal digestion, starch, dairy cow

Received June 3, 2013

Accepted December 5, 2013.

${ }^{1}$ Corresponding author: pierre.noziere@clermont.inra.fr

\section{INTRODUCTION}

Dairy cows of high genetic merit require an energydense diet to fulfill their production potential. This is why starchy cereals are so prevalent in the diets of high-producing dairy cows. However, cereals are also a human staple food, and compared with other feed components, they are expensive and their prices are expected to rise due to increasing costs of production and higher demand. Increases in cereal price also directly affect the profitability of dairy farms. For these reasons, the pressure is growing to reduce starch in dairy cow rations, making optimization of starch digestibility an important area of research if performance of milk production is to be maintained at a high level. In this context, the use of exogenous amylase as a feed additive for high-producing ruminants is of interest (McCarthy et al., 2013). Several studies have demonstrated that exogenous amylase preparations resistant to ruminal degradation are able to improve OM digestibility in dairy cows (Hristov et al., 2008; Klingerman et al., 2009; Gencoglu et al., 2010) or beef steers (DiLorenzo et al., 2011). This increased OM digestibility was associated, in some cases, with improved NDF digestibility, whereas no effect on starch digestibility (Gado et al., 2009; Klingerman et al., 2009; Gencoglu et al., 2010) or on true digestibility of $\mathrm{OM}$ in the rumen (Hristov et al., 2008) was found. Although there is abundant information on the use and mode of action of exogenous fibrolytic enzymes in ruminants (Beauchemin et al., 2003,2004 ), the number of studies on exogenous amylase is still small and the exact mechanisms by which amylases might improve digestibility have not been fully explored. The objective of the present work was to evaluate the effect of an exogenous amylase preparation on ruminal and total-tract digestion of low- and high-starch diets in dairy cows.

\section{MATERIALS AND METHODS}

The experiment was conducted in respect of the national legislation on animal care (Certificate of Authori- 
sation to Experiment on Living Animals, no. 004495, Ministry of Agriculture, France). The experiment was approved by the Auvergne regional ethic committee for animal experimentation (approval number CE30-10).

\section{Animals, Feeding, and Experimental Design}

Four Holstein first-lactation cows in mid lactation, weighing $545 \pm 25 \mathrm{~kg}$ (means $\pm \mathrm{SD}$ ) and at $82 \pm 3$ DIM at the beginning of the trial were used in a $4 \times$ 4 Latin square design. Six weeks before the start of the experiment, cows were fitted with ruminal cannulas (external and internal diameter $=123$ and $106 \mathrm{~mm}$ ) made of polyamide-polyvinyl chloride, and T-shaped cannulas (external and internal diameter $=30$ and $19 \mathrm{~mm}$ ) made of plastisol with a gutter-type flange placed at the proximal duodenum, before the bile duct entrance. Cannulas were manufactured in the INRA workshop (St-Genès Champanelle, France). Surgery was performed under general anesthesia. Four dietary treatments were applied to the cows during 4 successive 4 -wk periods. Treatments consisted of $30 \%$ (high starch) or 20\% (low starch) starch in the ration with or without addition of amylase.

The proportion of corn silage was the same for all diets (Table 1). Diets were isoenergetic on a net energy basis and isonitrogenous on $\mathrm{CP}$ and digestible protein basis, and not deficient in rumen-fermentable N (INRA, 2007). Differences in starch content were achieved by changes in formulation of the concentrate, with corn grain in the high-starch diet being replaced by soybean hulls and citrus pulp in the low-starch diet. Cows were housed in individual stalls and fed ad libitum during adaptation wk 1 and 2, and were fed at 95\% of ad libitum intake during adaptation wk 3 and during wk 4 when measurements were done. Rations were distributed as TMR twice a day. For practical reasons, cows were fed at $0900 \mathrm{~h}$ (60\% of the daily ration) and 1700 $\mathrm{h}$ (40\% of the daily ration) during wk 1 and 2 , and at 0945 and 2145 h (2 equal meals) during wk 3 and 4 . Fifteen minutes before each meal, each cow received 300 $\mathrm{g}$ of ground concentrate alone or supplemented with amylase [Ronozyme RumiStar 600 (CT), DSM Nutritional Products, Basel, Switzerland]. The enzyme dose $(10 \mathrm{~g} / \mathrm{d})$ was calculated to be equivalent to a dosage of 300 kilo novo units (KNU) $/ \mathrm{kg}$ of DM total ration, assuming an average daily feed intake of $20 \mathrm{~kg}$ of DM. Corn silage, hay, and additional concentrate without any enzyme supplementation were distributed after the ground concentrate had been entirely consumed. Water and mineral salt were freely available. Cows also received $200 \mathrm{~g} / \mathrm{d}$ of a mineral and vitamin complement (Galaphos midi duo, CCPA, Janzé, France; $4.5 \%$ P, $20 \% \mathrm{Ca}, \mathrm{Mg} 4.5 \%, 5 \% \mathrm{Na}$ ). Milking times were 0630 and $1530 \mathrm{~h}$.

\section{Measurements and Sampling}

Intake and Weight. Cows were weighed at the start of each experimental period. Water consumption

Table 1. Ingredients and chemical composition of the diets

\begin{tabular}{|c|c|c|c|c|}
\hline \multirow[b]{2}{*}{ Item } & \multicolumn{2}{|c|}{ High starch $(30 \%)$} & \multicolumn{2}{|c|}{ Low starch $(20 \%)$} \\
\hline & Control & Amylase & Control & Amylase \\
\hline \multicolumn{5}{|l|}{ Ingredient composition, $\%$ of DM } \\
\hline Corn silage & 59.0 & 59.0 & 58.5 & 58.9 \\
\hline Hay & 7.9 & 8.0 & 8.1 & 7.9 \\
\hline Pelleted high starch concentrate ${ }^{1}$ & 33.1 & 33.0 & - & - \\
\hline Pelleted low starch concentrate ${ }^{2}$ & - & - & 33.4 & 33.2 \\
\hline Amylase activity, ${ }^{3} \mathrm{KNU} / \mathrm{kg}$ of DM & & 354 & & 350 \\
\hline \multicolumn{5}{|l|}{ Chemical composition, $\mathrm{g} / \mathrm{kg}$ of DM } \\
\hline $\mathrm{CP}$ & 159 & 158 & 161 & 160 \\
\hline NDF & 313 & 314 & 349 & 349 \\
\hline $\mathrm{ADF}$ & 156 & 156 & 185 & 184 \\
\hline Starch & 299 & 299 & 197 & 199 \\
\hline \multicolumn{5}{|l|}{ Feed value, $/ \mathrm{kg}$ of $\mathrm{DM}$} \\
\hline $\mathrm{NE}_{\mathrm{L}}, \mathrm{MJ}$ & 6.97 & 6.97 & 6.76 & 6.76 \\
\hline Digestible protein, $\mathrm{g}$ of $\mathrm{PDI}^{4}$ & 105 & 105 & 104 & 104 \\
\hline \multicolumn{5}{|c|}{$\begin{array}{l}{ }^{1} \text { High starch concentrate: } 44.4 \% \text { corn grain, } 6.3 \% \text { citrus pulp, } 16.9 \% \text { tanned soybean meal, } 30 \% \text { soybean mea } \\
48,2.5 \% \text { urea, on a DM basis. }\end{array}$} \\
\hline \multicolumn{5}{|c|}{$\begin{array}{l}{ }^{2} \text { Low starch concentrate: } 1.3 \% \text { corn grain, } 15.6 \% \text { soybean hulls, } 33.8 \% \text { citrus pulp, } 16.9 \% \text { tanned soybean mea } \\
30 \% \text { soybean meal } 48,2.5 \% \text { urea, on a DM basis. }\end{array}$} \\
\hline \multicolumn{5}{|c|}{$\begin{array}{l}{ }^{3} \text { Amylase activity calculated from the actual analyzed enzyme activity of the test product Ronozyme RumiSta } \\
600 \text { [CT; DSM Nutritional Products, Basel, Switzerland; declared amylase activity: } 600 \text { kilo novo unit } \\
\text { (KNU)/g; analyzed amylase activity: } 669 \mathrm{KNU} / \mathrm{g} \text {, intake of the enzyme (10 g/cow per day), and actual DMI } \\
{ }^{4} \mathrm{PDI}=\text { protein digestible in the intestine (INRA, 2007). }\end{array}$} \\
\hline
\end{tabular}


was measured once a week. Intake was recorded $4 \mathrm{~d}$ per week on wk 1 and 2 , and daily on wk 3 and 4 . The $\mathrm{DM}$ content $\left(24 \mathrm{~h}\right.$ in a $103^{\circ} \mathrm{C}$ forced-air dry oven $)$ of feeds was measured once a week for concentrates and hay, and twice (wk 1, 2,3) or thrice (wk 4) a week for silage. The DM and $\mathrm{N}$ intakes were corrected for losses of volatile compounds (ethanol, $\mathrm{NH}_{3}$, and acetic and lactic acids) from corn silage during drying (Dulphy et al., 1975). A 100-g sample of each ingredient of the diet was collected daily during wk 4 of each period, pooled per period, and stored at $-20^{\circ} \mathrm{C}$ for silage or at ambient temperature for other ingredients until analysis of chemical composition. When refusals exceeded $1 \mathrm{~kg}$, DM content was measured and refusals were stored at $-20^{\circ} \mathrm{C}$ for subsequent analysis of chemical composition; otherwise, the chemical composition was assumed to be similar to the offer.

Total-Tract Digestibility, $N$ Balance, Nutrient Flow, and Microbial Synthesis. Total-tract digestibility and $\mathrm{N}$ balance measurements were performed in wk 4 by total feces and urine collection during $6 \mathrm{~d}$. A urine collection device fixed to the animal was used to separate urine from feces. The device was connected by a flexible pipe to a 30-L carboy containing $500 \mathrm{~mL}$ of $10 \%$ sulfuric acid. Fresh weight (feces and urines) and DM content (feces) were determined daily at $0900 \mathrm{~h}$. Total daily fecal excretion of each cow was mixed and a $0.5 \%$ aliquot pooled over the 6 - $\mathrm{d}$ collection period and stored at $-20^{\circ} \mathrm{C}$. Similarly, for urine, a $1 \%$ aliquot of the daily excretion of each cow was sampled, pooled, and stored at $-20^{\circ} \mathrm{C}$.

Duodenal digesta fluxes were determined using ytterbium(III) chloride $\left(\mathrm{YbCl}_{3}\right)$ as an external indigestible marker (Siddons et al., 1985). A solution of $1 \mathrm{~g}$ of $\mathrm{Yb}$ was continuously infused in the rumen at a rate of $1.2 \mathrm{~L} / \mathrm{d}$ through the ruminal cannula using a peristaltic pump for 10 consecutive days, (i.e., $6 \mathrm{~d}$ before the first duodenal sampling) to ensure a steady state (Owens and Hanson, 1992). Twelve duodenal samples of $250 \mathrm{~mL}$, representing 2-h intervals over a day, were collected over $3 \mathrm{~d}$ in wk 4 . Samples were pooled per animal and per period and stored at $-20^{\circ} \mathrm{C}$.

For calculation of bacterial $\mathrm{N}$ flow and protein synthesis, rumen content samples were taken in each period on the first day of wk 4 , before and $2.5 \mathrm{~h}$ after the morning feeding. The solid and liquid phases were separated by filtration through a polyester monofilament fabric (250$\mu \mathrm{m}$ mesh aperture). Solid-adherent bacteria (SAB) in the retentate and liquid-associated bacteria $(\mathbf{L A B})$ in the filtrate were isolated by washing, stomaching, and differential centrifugation, as described in Bauchart et al. (1990). Pre- and postfeeding bacterial samples were pooled and stored at $-20^{\circ} \mathrm{C}$.
Rumen Fermentation Traits. Rumen contents were sampled before and at 1, 2.5, 5, and $8 \mathrm{~h}$ after the morning feeding on 2 consecutive days. Samples were maintained on a magnetic stirrer for $\mathrm{pH}$ determination using a digital $\mathrm{pH}$ meter (CG837, $\mathrm{Ag} / \mathrm{AgCl}$ electrode, Schott Geräte, Hofheim, Germany) and then immediately strained through a $250-\mu \mathrm{m}$-pore polyester monofilament fabric. The rumen $\mathrm{pH}$ was also measured continuously using immersed probes (Sentinel Rumen Monitoring system, Kahne Ltd., Auckland, New Zealand). For VFA, $0.8 \mathrm{~mL}$ of rumen filtrate was transferred to a microcentrifuge tube containing 0.5 $\mathrm{mL}$ of a $0.5 \mathrm{~N} \mathrm{HCl}$ solution containing $2 \%$ (wt/vol) metaphosphoric acid and $0.4 \%$ (wt/vol) crotonic acid, kept at $4^{\circ} \mathrm{C}$ for at least $2 \mathrm{~h}$, and stored at $-20^{\circ} \mathrm{C}$ until analysis. For ammonia, $1 \mathrm{~mL}$ of rumen filtrate was transferred to a microcentrifuge tube containing $0.1 \mathrm{~mL}$ of $5 \%$ orthophosphoric acid and stored at $-20^{\circ} \mathrm{C}$ until analysis. Viscosity was measured on the rumen filtrate $5 \mathrm{~h}$ after feeding using a micro Ubbelohde viscometer and a ViscoClock (Schott Geräte).

Rumen Microbial Traits. For protozoa, strained rumen fluid samples collected $2.5 \mathrm{~h}$ after the morning feeding were mixed with a methyl green-formalin solution in a 1:1 ratio and stored at room temperature in the dark until used for counting. Samples were diluted in methyl green-formalin solution if necessary and enumeration was done using a Neubauer counting chamber. The activities of carboxymethyl cellulase (CMCase), xylanase, and amylase from SAB were determined before and $2.5 \mathrm{~h}$ after the morning feeding according to the procedure described by Martin et al. (1993). Total genomic DNA was extracted from rumen samples collected before and $2.5 \mathrm{~h}$ after feeding using the method described by $\mathrm{Yu}$ and Morrison (2004) and quantified by spectrophotometry using a NanoQuant Plate on an Infinity spectrophotometer (Tecan, Männedorf, Switzerland). The cellulolytic bacteria Fibrobacter succinogenes, Ruminococcus flavefaciens, and Ruminococcus albus; the starch-degrading lactateproducing Streptococcus bovis; the Prevotella spp.; and total bacteria were quantified by quantitative PCR (qPCR) using primers targeting the 16S rRNA gene, as reported before (Edwards et al., 2007; Stevenson and Weimer, 2007; Lettat et al., 2012). Denaturing gradient gel electrophoresis PCR targeting the bacterial V3 variable region of the $16 \mathrm{~S}$ rRNA gene was performed as described before (Sadet et al., 2007).

Milk Production and Composition. Cows were milked in their stalls twice daily at 0630 and $1530 \mathrm{~h}$. Milk yield was recorded by an automatic infrared flowmeter (DeLaval, Elancourt, France). Aliquots (100 mL) of morning and evening milkings were taken $2 \mathrm{~d}$ (wk 1 , 
2 and 3 ) or $3 \mathrm{~d}$ (wk 4) per week for determination of milk composition.

\section{Chemical Analysis}

Milk fat, protein, and lactose concentrations were determined by infrared spectrophotometry (Combi-Foss 5000, Foss Electric, Hillerød, Denmark). Milk urea was determined by the dimethylaminobenzaldehyde colorimetric method (Potts, 1967). Milk fat, protein, lactose, and urea yields were calculated from morning and evening milk yields and composition. Diet ingredients, refusals, duodenal contents, and feces were analyzed for $\mathrm{DM}\left(103^{\circ} \mathrm{C}\right.$ for $\left.24 \mathrm{~h}\right)$, ash $\left(550^{\circ} \mathrm{C}\right.$ for $\left.6 \mathrm{~h}\right)$, and $\mathrm{N}$ by Kjeldahl method (AOAC, 1990). Neutral detergent fiber using $\alpha$-amylase and ADF (Van Soest et al., 1991) were analyzed on samples dried at $60^{\circ} \mathrm{C}$ for $48 \mathrm{~h}$ and ground through a 1-mm screen. Starch was analyzed by spectrophotometry after enzymatic analysis on fresh feeds and refusals and on lyophilized duodenal and fecal samples (Faisant et al., 1995). Ytterbium concentration was determined in infusion solutions, feces, and duodenal contents by atomic absorption spectrophotometry (model 2380 spectrophotometer, Perkin-Elmer, Bois d'Arcy, France) at a wavelength of $398.8 \mathrm{~nm}$ with an acetylene $/ \mathrm{N}_{2} \mathrm{O}$ flame after extraction of the marker from lyophilized samples (Hart and Polan, 1984). Purine and pyrimidine bases were measured in $\mathrm{LAB}, \mathrm{SAB}$, and duodenal contents, as described by Fanchone et al. (2013). Briefly, lyophilized samples were hydrolyzed by perchloric acid $(70 \%)$ at $100^{\circ} \mathrm{C}$ and neutralized by addition of sodium hydroxide $(0.6 N)$. Purine and pyrimidine bases were then quantified using HPLC (Waters, Saint Quentin en Yvelines, France. Nitrogen (Dumas method) and ash $\left(550^{\circ} \mathrm{C}\right.$ for $\left.6 \mathrm{~h}\right)$ were measured in lyophilized LAB and SAB samples. For VFA and ammonia determination, samples from 2 consecutive days were pooled per animal for each period and sampling time. The VFA content of the rumen liquid was determined by GLC using crotonic acid as an internal standard (Morgavi et al., 2003). Ammonia content of rumen liquid and of duodenal samples was determined by colorimetry using the phenol-hypochlorite method (Weatherburn, 1967) on a spectrophotometer (Infinity M200, Tecan Austria GmbH, Grödig, Austria). $\alpha$-Amylase concentration in samples of the test product Ronozyme RumiStar 600 (CT) was measured according to Jung and Vogel (2008). Samples were extracted with $0.1 M$ sodium phosphate buffer $\mathrm{pH} 5.0$ at room temperature. The centrifuged extract was appropriately diluted with $0.1 M$ sodium phosphate buffer, $\mathrm{pH}$ 5.0, and incubated in the presence of a dyed starch (Red Starch, Megazyme International Ireland, Bray, Ireland) at $40^{\circ} \mathrm{C}$ for $1 \mathrm{~h}$. The reaction was stopped with ethanol (95\%), which precipitates substrate molecules of high molecular weight. The precipitated high-molecular-weight starch fragments were removed by centrifugation, and absorbance in the supernatant was measured at 510 $\mathrm{nm}$. The $\alpha$-amylase in the assay solution was quantified by using an $\alpha$-amylase standard curve and the activity was expressed as KNU per kilogram. One KNU is defined as the amount of enzyme that releases, in a 2-step reaction containing $\alpha$-amylase and excess amount of $\alpha$-glucosidase, $6 \mu \mathrm{mol}$ of $p$-nitrophenol/min from 1.86 $\mathrm{m} M \quad$ 4,6-ethylidene-G7-p-nitrophenyl-maltoheptaoside at $\mathrm{pH} 7.0$ and $37^{\circ} \mathrm{C}$.

\section{Calculations and Statistical Analysis}

Duodenal DM flows were calculated as the ratio between daily amount of $\mathrm{Yb}$ excreted in feces and $\mathrm{Yb}$ content of duodenal samples. Daily amount of DM and $\mathrm{Yb}$ excreted in feces were corrected for the estimated amount of undigestible DM removed by sampling, assuming 0.4 and $0.5 \mathrm{~g}$ of undigestible $\mathrm{DM} / \mathrm{g}$ of $\mathrm{DM}$ at the ruminal and duodenal levels, respectively. Microbial protein synthesis was calculated using a reference bacterial sample consisting either in LAB, or in a mix (MB) of $\mathrm{LAB}$ and $\mathrm{SAB}$ at a 44:56 ratio; that is, a 25:75 ratio in the rumen, with an outflow rate of 0.12 and $0.05 \mathrm{~h}^{-1}$, respectively (Doreau and Ottou, 1996). Ruminal protein balance was calculated as the difference between $\mathrm{N}$ intake and duodenal NAN multiplied by 6.25 , and expressed as grams of $\mathrm{CP}$ per gram of DMI. The $4 \%$ FCM was calculated as milk yield $\times(0.4$ $+0.015 \times$ milk fat concentration), with milk yield and milk fat concentration being expressed in kilograms per day and grams per kilogram, respectively.

Data were analyzed by ANOVA using the Mixed procedure of SAS software, version 9 (SAS Institute Inc., Cary, NC), with mean per animal and treatment as experimental unit. The model included cow as a random effect, and period, starch (high vs. low), exogenous amylase (without vs. with), time, and interactions starch $\times$ amylase, starch $\times$ time, amylase $\times$ time, and starch $\times$ amylase $\times$ time as fixed effects. For rumen kinetics, the REPEATED statement within the Mixed procedure of SAS was used. Significance was declared at $P<0.05$. Probability values between 0.05 and 0.10 were considered as trends.

\section{RESULTS}

\section{BW, DMI, Nitrogen Partition, and Milk Yield and Composition}

The BW of animals increased during the trial from 547 to $572 \mathrm{~kg}$ between periods 1 and $4(P=0.04)$. No 
Table 2. Effects of starch level and amylase addition on BW, DMI, milk yield and composition, and N partition ${ }^{1}$

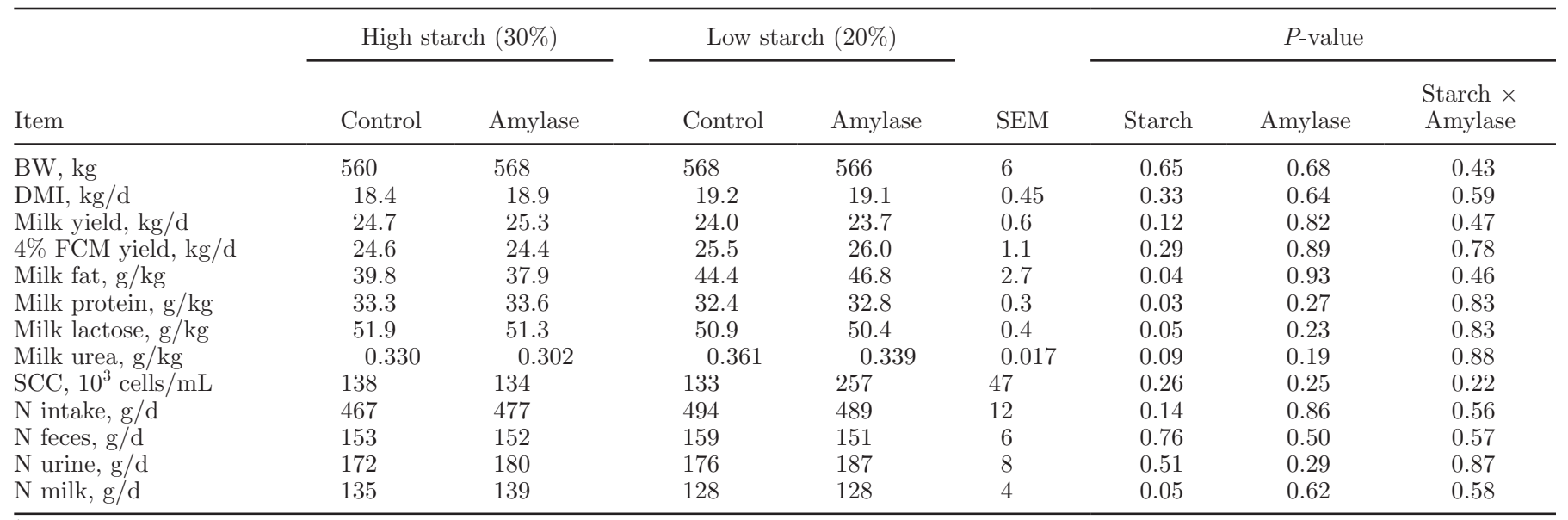

${ }^{1}$ Means of 4 first-lactation cows per treatment.

effect of treatment was observed on BW, DMI, milk yield, $\mathrm{N}$ intake, or $\mathrm{N}$ excretion in urine and feces (Table 2 ). The high-starch diet increased milk protein and lactose contents as well as $\mathrm{N}$ secretion in milk but it decreased milk fat and urea concentrations compared with the low-starch diet. No effect of exogenous amylase and no starch $\times$ amylase interactions were observed for these traits.

\section{Feed Digestion and Ruminal Microbial Synthesis}

The high-starch diet had a negative effect on totaltract digestibility of NDF and ADF but increased that of starch (Table 3). In contrast, no effects of starch level were observed on total-tract apparent DM and OM digestibility; ruminal digestibility of OM, NDF, ADF, and starch; duodenal microbial and nonmicrobial $\mathrm{N}$ flows; or efficiency of microbial protein synthesis. Amylase supplementation increased ruminal digestibility of starch by $6.5 \%$. Amylase supplementation also increased the true ruminal digestibility of $\mathrm{OM}$ by an average of $4 \%$, irrespective of the microbial population (LAB or MB) used in calculations or the starch level of the diet. However, the lower ruminal digestibility of OM and starch in the absence of exogenous amylase addition was compensated postruminally, as no differences were observed on total-tract digestibility of $\mathrm{OM}$ and starch. Also, we observed no effect of amylase supplementation on DM total-tract digestibility, ruminal and total-tract digestibility of NDF and ADF, duodenal N flows, or efficiency of microbial synthesis.

\section{Ruminal Fermentations}

Mean ruminal $\mathrm{pH}$ and $\mathrm{N}-\mathrm{NH}_{3}$ did not differ among treatments, averaging 6.30 and $261 \mathrm{mg} / \mathrm{L}$, respectively
(Table 4). Similar conclusions were obtained with continuous measurement of $\mathrm{pH}$ by probes (not shown). A starch $\times$ enzyme interaction $(P=0.04)$ revealed that minimal $\mathrm{pH}$ was slightly higher with the low-starch control diet (5.52) than with other treatments (on average 5.42); the maximal $\mathrm{pH}$ was slightly higher $(P=$ $0.05)$ with high-starch than with low-starch diets $(7.02$ vs 6.90 , respectively). Time under $\mathrm{pH} 5.8$ was low and similar among treatments, averaging $9 \mathrm{~min} / \mathrm{d}$ (data not shown). High-starch diets induced a shift in the proportion of VFA with lower acetate and a relative higher propionate, isovalerate, valerate, and caproate (Table 4). These differences were mainly observed between diets supplemented with amylase. Amylase supplementation tended to increase total ruminal VFA concentration in high-starch diets. No interaction between sampling time and experimental factors (starch level or amylase addition) was observed on rumen fermentation measurements, except a trend for isobutyrate (starch $\times$ amylase $\times$ time, $P=0.05)$. Amylase supplementation also marginally reduced $(P=0.04)$ the viscosity of rumen fluid from 1.23 to 1.15 cSt (centistokes, where $1 \mathrm{cSt}=1 \mathrm{~mm}^{2} / \mathrm{s}$ ) independently of the diet (data not shown).

\section{Rumen Microbial Populations and Enzymatic Activities}

The concentration of total bacteria and that of selected bacterial populations, as estimated by qPCR of $16 \mathrm{~S}$ rRNA gene copies, did not show any major change among treatments from samples taken before feeding (data not shown). However, some effects were observed after feeding; the high-starch diet slightly increased the concentration of total bacteria, and amylase supplementation slightly decreased the concentration of $F$. 
Table 3. Effects of starch level and amylase addition on OM, NDF, ADF, starch and N digestion, and microbial synthesis ${ }^{1}$

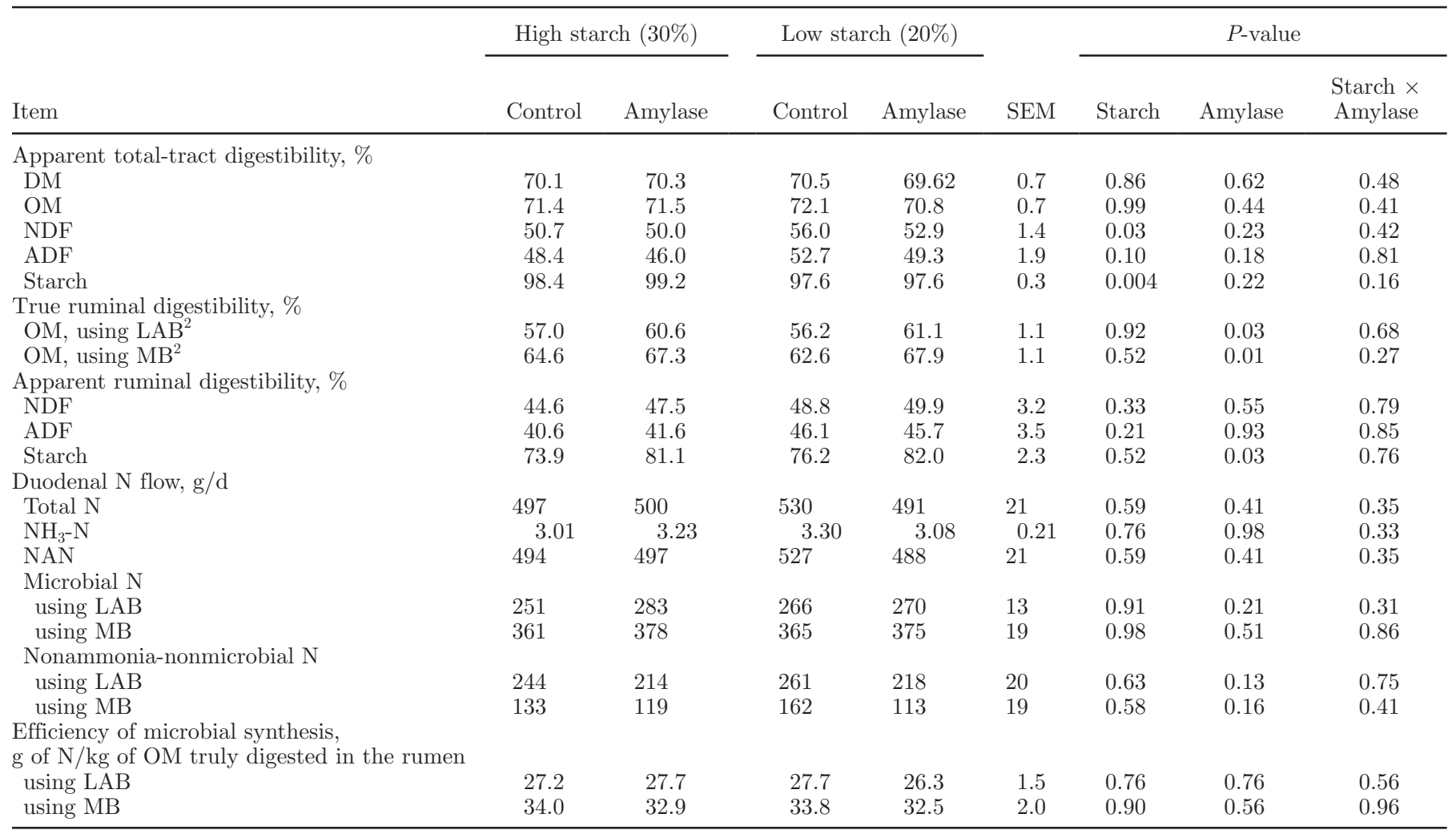

${ }^{1}$ Means of 4 first-lactation cows per treatment.

${ }^{2}$ Using liquid associated bacteria (LAB) or mixed bacteria (MB) as microbial reference sample.

succinogenes (Table 5). Amylase supplementation also affected the proportion of Prevotella spp. relative to total bacteria that decreased in the low-starch diet and increased in the high-starch diet. The numbers of total rumen protozoa, total small entodiniomorphs, total large entodiniomorphs, and Dasytrica were not affected by the level of starch or by amylase supplementation. In contrast, the numbers of Isotricha were lower in high-starch diets and tended to be lower in amylase-supplemented diets. Similarly to qPCR data

Table 4. Effects of starch level, amylase addition, and sampling time ${ }^{1}$ on rumen $\mathrm{pH}, \mathrm{N}_{-} \mathrm{NH}_{3}$ concentration, and VFA concentrations and molar proportions $^{2}$

\begin{tabular}{|c|c|c|c|c|c|c|c|c|c|}
\hline \multirow[b]{2}{*}{ Item } & \multicolumn{2}{|c|}{ High starch (30\%) } & \multicolumn{2}{|c|}{ Low starch $(20 \%)$} & \multirow[b]{2}{*}{ SEM } & \multicolumn{4}{|c|}{$P$-value } \\
\hline & Control & Amylase & Control & Amylase & & Starch & Amylase & $\begin{array}{c}\text { Starch } \times \\
\text { Amylase }\end{array}$ & Time \\
\hline $\mathrm{N}-\mathrm{NH}_{3}, \mathrm{mg} / \mathrm{L}$ & 257 & 280 & 270 & 235 & 26 & 0.55 & 0.82 & 0.27 & 0.03 \\
\hline Total VFA, $\mathrm{m} M$ & 114.2 & 122.8 & 120.9 & 120.0 & 2.8 & 0.49 & 0.17 & 0.09 & $<0.0001$ \\
\hline \multicolumn{10}{|c|}{ VFA molar proportions, $\mathrm{mol} / 100 \mathrm{~mol}$} \\
\hline Isobutyrate $^{3}$ & 0.61 & 0.64 & 0.64 & 0.59 & 0.05 & 0.92 & 0.82 & 0.44 & $<0.0001$ \\
\hline Butyrate & 15.2 & 13.4 & 14.6 & 14.1 & 0.55 & 0.95 & 0.05 & 0.26 & $<0.0001$ \\
\hline Isovalerate & 1.37 & 0.77 & 0.85 & 0.69 & 0.08 & $<0.0001$ & $<0.0001$ & 0.005 & $<0.0001$ \\
\hline Valerate & 1.36 & 2.09 & 1.13 & 1.39 & 0.10 & $<0.0001$ & $<0.0001$ & 0.02 & $<0.0001$ \\
\hline Caproate & 0.51 & 0.80 & 0.45 & 0.58 & 0.05 & 0.009 & $<0.0001$ & 0.15 & $<0.0001$ \\
\hline Acetate:propionate & 4.04 & 3.05 & 3.77 & 3.83 & 0.11 & 0.03 & $<0.0001$ & $<0.0001$ & 0.001 \\
\hline
\end{tabular}

${ }^{1}$ Before and $1,2.5,5$, and $8 \mathrm{~h}$ after the morning feeding.

${ }^{2}$ Means of 4 first-lactation cows $\times 5$ sampling times per treatment.

${ }^{3}$ Starch $\times$ amylase $\times$ time interaction: $P=0.052$. 
Table 5. Effects of starch level and amylase addition on selected bacteria and protozoa $2.5 \mathrm{~h}$ after feeding ${ }^{1}$

\begin{tabular}{|c|c|c|c|c|c|c|c|c|}
\hline \multirow[b]{2}{*}{ Item } & \multicolumn{2}{|c|}{ High starch $(30 \%)$} & \multicolumn{2}{|c|}{ Low starch $(20 \%)$} & \multirow[b]{2}{*}{ SEM } & \multicolumn{3}{|c|}{$P$-value } \\
\hline & Control & Amylase & Control & Amylase & & Starch & Amylase & $\begin{array}{l}\text { Starch } \times \\
\text { Amylase }\end{array}$ \\
\hline \multicolumn{9}{|c|}{$\begin{array}{l}\text { Bacteria, } \log _{10} 16 \mathrm{~S} \text { rRNA copy number/g } \\
\text { of DM rumen content }\end{array}$} \\
\hline Total bacteria & 10.8 & 10.7 & 10.7 & 10.6 & 0.041 & 0.04 & 0.17 & 0.87 \\
\hline Prevotella spp. & 10.3 & 10.2 & 10.2 & 10.1 & 0.057 & 0.15 & 0.23 & 0.44 \\
\hline$\%$ in total bacteria & 2.98 & 2.48 & 3.48 & 2.91 & 0.335 & 0.22 & 0.16 & 0.92 \\
\hline Ruminococcus albus & 7.77 & 7.77 & 7.69 & 7.70 & 0.155 & 0.25 & 0.89 & 0.96 \\
\hline$\%$ in total bacteria & 0.11 & 0.12 & 0.13 & 0.14 & 0.037 & 0.30 & 0.51 & 0.98 \\
\hline Ruminococcus flavefaciens & 8.37 & 8.33 & 8.14 & 8.20 & 0.089 & 0.08 & 0.92 & 0.58 \\
\hline$\%$ in total bacteria & 0.41 & 0.42 & 0.28 & 0.38 & 0.083 & 0.33 & 0.51 & 0.61 \\
\hline Streptococcus bovis & 6.87 & 6.73 & 6.73 & 6.75 & 0.103 & 0.46 & 0.47 & 0.33 \\
\hline$\%$ in total bacteria & 0.02 & 0.01 & 0.01 & 0.01 & 0.004 & 0.95 & 0.61 & 0.21 \\
\hline Dasytricha & 2.53 & 2.42 & 2.45 & 2.45 & 0.221 & 0.91 & 0.80 & 0.80 \\
\hline
\end{tabular}

${ }^{1}$ Means of 4 first-lactation cows per treatment

on bacterial populations, the bacterial community as evaluated by denaturing gradient gel electrophoresis analysis revealed no clear effect of treatments (data not shown).

Starch level as well as amylase supplementation did not affect xylanase and CMCase activities of SAB (Table 6). In contrast, total amylase activity increased in the high-starch diet and was higher with diets supplemented with amylase. The effect of amylase supplementation was more marked after feeding in the high-starch diet and before feeding in the low-starch diet (starch $\times$ amylase $\times$ time interaction, $P=0.02$ ).

\section{Fecal Fermentations}

The main observed effect on fecal fermentations (Table 7) was a reduction in total VFA concentration in high-starch diets supplemented with amylase, whereas an opposite effect was observed with the low-starch diet (starch $\times$ amylase interaction). The proportion of butyrate was slightly increased in high-starch diets.

\section{DISCUSSION}

This $4 \times 4$ Latin square trial was designed to obtain robust information on digestive traits, rather than animal production performance. Therefore, only digestive aspects, with a particular attention to the effects of amylase additive, are discussed.

The main observed effects of exogenous amylase were on ruminal digestion of starch, which increased by $6.5 \%$ on average. In contrast, Hristov et al. (2008) reported no effect of exogenous amylase on ruminal starch digestibility in dairy cows fed a hay-based diet containing $21 \%$ starch. Although differences in responses between studies could be explained by differences in enzyme preparation or diet composition, the present work showed, for the first time to our knowledge, the ability of an exogenous amylase preparation to improve ruminal starch digestion in vivo. This finding was in line with the concomitant increase in true ruminal OM digestibility, whereas ruminal NDF digestibility was not affected. In agreement with the increased ruminal starch digestibility, the amylase activity isolated from $\mathrm{SAB}$ increased in amylase-supplemented diets. Given that rumen contents are washed before enzyme extraction, only microbial enzymes are expected to be isolated, with no contamination from the exogenous amylase activity, although adsorption (or attachment) of the exogenous enzyme to small particles cannot be excluded. The increase in microbial amylase activity and ruminal starch digestibility observed in this trial was not associated with changes in the bacterial community or changes in the amylolytic Strep. bovis. Many bacteria are able to utilize starch as an energy source and changes might have been too subtle to be picked up by the techniques used. The results on protozoa were contrasting, as exogenous amylase tended to decrease the number of small entodiniomorphs and holotrichs, which are the groups involved in degradation of starch and sugars.

Despite the improved ruminal starch digestion with amylase supplementation, total-tract starch digestion was not modified, reflecting the ability of the intes- 
Table 6. Effects of starch level, amylase addition, and sampling time on xylanase, carboxymethyl cellulase (CMCase), and amylase activities of solid-associated microorganisms in the rumen ${ }^{1}$

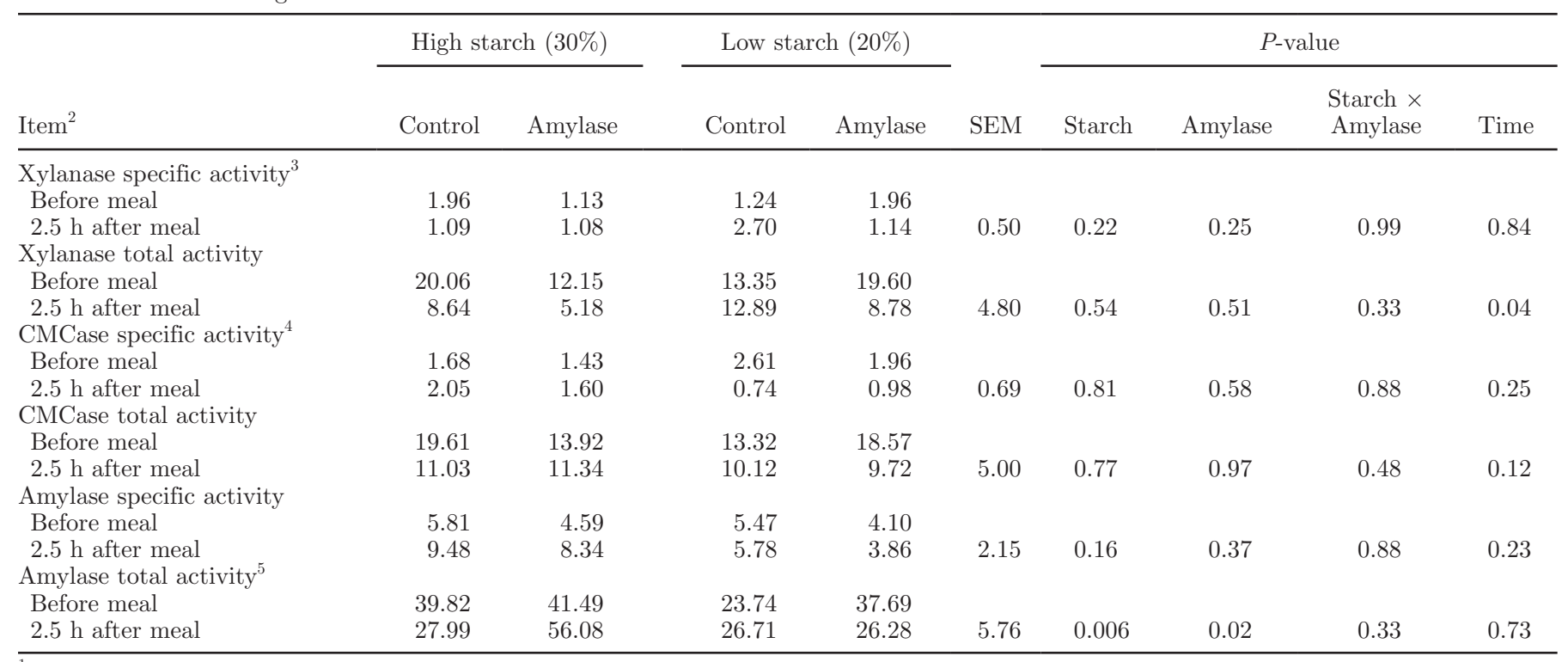

${ }^{1}$ Means of 4 first-lactation cows per sampling time per treatment.

${ }^{2}$ Specific activity measured in $\mu \mathrm{mol}$ of reducing sugar/mg of protein per hour; total activity measured in $\mu$ mol of reducing sugar/g of DM per hour.

${ }^{3}$ Starch $\times$ amylase $\times$ time interaction: $P=0.041$.

${ }^{4}$ Starch $\times$ time interaction: $P=0.099$.

${ }^{5}$ Starch $\times$ amylase $\times$ time interaction: $P=0.022$.

tine to digest starch escaping ruminal digestion, which can be up to $3 \mathrm{~g} / \mathrm{d}$ per $\mathrm{kg}$ of BW (Huntington, 1997; Offner and Sauvant, 2004; Nozière et al., 2010). Previous studies reported a numerical increase in total-tract digestibility of starch with amylase-supplemented diets in dairy cows (Hristov et al., 2008; Klingerman et al., 2009; Weiss et al., 2011) or in beef steers (DiLorenzo et al., 2011), but it never exceeded $1.7 \%$ and was not always observed (McCarthy et al., 2013). It is worth noting that starch was highly degradable in the present work, with an average digestibility of 78 and $98 \%$ at the ruminal and total-tract levels, respectively. These values are in accordance with the expected values estimated from INRA (2007) feed tables.

No effect of amylase supplementation was observed on ruminal and total-tract digestibility of NDF and ADF, which is in good agreement with Hristov et al. (2008) and Weiss et al. (2011). In contrast, several studies in dairy cows (Gado et al., 2009; Klingerman et al., 2009; Gencoglu et al., 2010) and beef steers (DiLorenzo et al., 2011) reported a numerical increase in NDF total digestibility. However, in all these studies, digestibility was not directly measured from total feces collection but was calculated from partial collection of feces or marker

Table 7. Effects of starch level and amylase addition on fecal $\mathrm{pH}$ and VFA concentration and proportion ${ }^{1}$

\begin{tabular}{|c|c|c|c|c|c|c|c|c|}
\hline \multirow[b]{2}{*}{ Item } & \multicolumn{2}{|c|}{ High starch (30\%) } & \multicolumn{2}{|c|}{ Low starch $(20 \%)$} & \multirow[b]{2}{*}{ SEM } & \multicolumn{3}{|c|}{$P$-value } \\
\hline & Control & Amylase & Control & Amylase & & Starch & Amylase & $\begin{array}{l}\text { Starch } \times \\
\text { Amylase }\end{array}$ \\
\hline $\mathrm{DM}, \%$ & 12.6 & 13.6 & 13.2 & 12.9 & 0.32 & 0.76 & 0.32 & 0.05 \\
\hline Total VFA, mM & 71.5 & 56.9 & 57.0 & 64.3 & 4.34 & 0.43 & 0.42 & 0.02 \\
\hline \multicolumn{9}{|c|}{ VFA molar proportions, $\mathrm{mol} / 100 \mathrm{~mol}$} \\
\hline Butyrate & 6.6 & 6.0 & 5.2 & 5.4 & 0.40 & 0.003 & 0.55 & 0.20 \\
\hline Isobutyrate + isovalerate & 0.9 & 0.9 & 0.9 & 1.0 & 0.10 & 0.52 & 0.45 & 0.64 \\
\hline Valerate + caproate & 0.7 & 0.7 & 0.7 & 0.8 & 0.03 & 0.03 & 0.03 & 0.23 \\
\hline
\end{tabular}

${ }^{1}$ Means of 4 first-lactation cows per treatment 
dilution. The ruminal digestion of NDF accounted for, on average, $91 \%$ of their total digestion. This is in good agreement with published data (Nozière et al., 2010). The difference in NDF digestibility between the high-starch and low-starch diets may be explained by the high digestibility of NDF in the concentrate fed in the low-starch diet and by a lower digestibility of forage NDF in the high-starch diet. The former is likely the main explanation because other traits such as $\mathrm{pH}$, fibrolytic activity of SAB, and numbers of fibrolytic microbes all indicate that the rumen fibrolytic function was not affected by the high-starch diet. Under these conditions, which were favorable for fiber degradation, amylase supplementation could not have had any additional positive effect on this trait.

The ruminal metabolism of nitrogen; that is, the duodenal flows of microbial and nonmicrobial $\mathrm{N}$ fractions and $\mathrm{N}^{-\mathrm{NH}_{3}}$ ruminal concentrations, was not affected by treatments. Although amylase supplementation increased the true digestibility of $\mathrm{OM}$ in the rumen, this positive effect did not translate into a higher microbial protein synthesis in the present study. In contrast, Gado et al. (2009), with a low $\mathrm{N} \operatorname{diet}(10.3 \%$ of $\mathrm{CP}$ ) reported increased microbial $\mathrm{N}$ duodenal flow with a commercial exogenous enzyme mixture but this flow was estimated from urinary excretion of allantoin and uric acid. Hristov et al. (2008), using ${ }^{15} \mathrm{~N}$ as a microbial marker, reported no effect of exogenous amylase on microbial $\mathrm{N}$ duodenal flows, which is in good agreement with the present results. As already reported (Doreau and Ottou, 1996; Fanchone et al., 2013), the microbial flow to the duodenum was higher when using $\mathrm{MB}$ as microbial reference compared with LAB. However, the LAB method led to a more realistic quantification of dietary $\mathrm{N}$ degradation in the rumen (on average 59 vs. $80 \%$ of $\mathrm{N}$ intake with $\mathrm{LAB}$ and $\mathrm{MB}$, respectively, assuming $2 \mathrm{~g}$ of endogenous $\mathrm{N} / \mathrm{kg}$ of DMI) compared with the value of $62 \%$ calculated from INRA (2007) feed tables.

Total bacterial numbers measured by qPCR were also in agreement with the measures on microbial protein flow to the small intestine. The $\mathrm{N}^{-\mathrm{NH}_{3}}$ concentration in the rumen was high, on average $260 \mathrm{mg}$ of $\mathrm{N}_{-} \mathrm{NH}_{3} / \mathrm{L}$, whereas rumen $\mathrm{N}$ balance did not differ from zero. This may be due to both the high level of dietary rumendegradable $\mathrm{N}$, and the high level of $\mathrm{N}$ recycling via saliva favored by a high level of dietary NDF $(>30 \%$ DM) mainly provided by forage. The high NDF level may also have stimulated saliva production, helping to stabilize mean rumen $\mathrm{pH}$ in the high-starch diet.

The main effect of amylase supplementation on VFA was observed with the high-starch diet. Amylase supplementation tended to increase total concentration and induced a shift in the molar proportions of propionate and valerate that increased at the expense of acetate and butyrate. It may be expected that the glucose released from starch hydrolysis by the exogenous amylase was predominantly fermented via the odd-chain VFA pathways. This may contribute to regulate the production of ATP required for microbial growth, because these odd-VFA pathways produce less ATP per mole of fermented carbon (Sauvant and Van Milgen, 1995). Nevertheless, changes were rather moderate, which is in line with DeFrain et al. (2005) and Hristov et al. (2008), who reported no change in VFA profiles following amylase supplementation. In the present work, the pattern of major VFA was only slightly modified by starch level. This is in line with the fact that the digested NDF:digested OM ratio was only slightly modified between high-starch and low-starch diets (from 0.23 to 0.28 , respectively). This ratio has been shown to be the main explanatory variable of VFA molar proportions in the rumen (Nozière et al., 2010), with an expected minor change in molar proportions of acetate, propionate, and butyrate $(-1.3 \pm 1.5,+0.9 \pm 1.5$, and $+0.34 \pm 0.9$ $\mathrm{mol} / \mathrm{mol}$, respectively) when this ratio increased from 0.23 to 0.28 .

\section{CONCLUSIONS}

The exogenous amylase used in this study improved starch digestion in the rumen of first-lactation cows, whereas the previously reported effect on NDF digestion was not confirmed. The first-lactation cows used in this trial had moderate intakes and production levels and, based on the numerous indicators of rumen function measured, ruminal fermentation was well balanced, as reflected by the good feed digestibility. Further research on high-producing animals is necessary to assess the usefulness of this exogenous amylase to improve starch digestion when ruminal conditions are less favorable.

\section{ACKNOWLEDGMENTS}

The authors thank their colleagues of the Unité Mixte de Recherches sur les Herbivores (UMRH) and of the Unité Expérimentale sur les Ruminants de Theix (UERT), INRA, St-Genès Champanelle, France: S. Laverroux and H. Albarello (UMRH) for management of the experiment; D. Durand (UMRH) and P. Gaydier (UERT) for animal surgery; S. Rudel, B. Robert, and the staff of "Les Cèdres" (UERT) for animal care and help with sampling; and P. Amblard, L. Genestoux, D. Graviou, J. Portelli, and the staff of "DIMA" (UMRH) for their technical participation.

\section{REFERENCES}

AOAC. 1990. Official Methods of Analysis. Vol. 15th ed. Association of Official Analytical Chemists (AOAC), Arlington, VA. 
Bauchart, D., F. Legay-Carmier, M. Doreau, and B. Gaillard. 1990. Lipid metabolism of liquid-associated and solid-adherent bacteria in rumen contents of dairy cows offered lipid-supplemented diets. Br. J. Nutr. 63:563-578.

Beauchemin, K. A., D. Colombatto, D. P. Morgavi, and W. Z. Yang. 2003. Use of exogenous fibrolytic enzymes to improve feed utilization by ruminants. J. Anim. Sci. 81(E-Suppl.):E37-E47.

Beauchemin, K. A., D. Colombatto, D. R. Morgavi, W. Z. Yang, and L. M. Rode. 2004. Mode of action of exogenous cell-wall degrading enzymes for ruminants. Can. J. Anim. Sci. 77:646-653.

DeFrain, J. M., A. R. Hippen, K. F. Kalscheur, and J. M. Tricarico. 2005. Effects of dietary $\alpha$-amylase on metabolism and performance of transition dairy cows. J. Dairy Sci. 88:4405-4413.

DiLorenzo, N., D. R. Smith, M. J. Quinn, M. L. May, C. H. Ponce, W. Steinberg, M. A. Engstrom, and M. L. Galyean. 2011. Effects of grain processing and supplementation with exogenous amylase on nutrient digestibility in feedlot diets. Livest. Sci. 137:178-184.

Doreau, M., and J. F. Ottou. 1996. Influence of niacin supplementation on in vivo digestibility and ruminal digestion in dairy cows. J. Dairy Sci. 79:2247-2254.

Dulphy, J.-P., C. Demarquilly, M. Henry, M. Jailler, J. Jamot, and L. L'hotelier. 1975. Perte de composés volatils lors de la détermination a l'étuve de la teneur en matière sèche des ensilages. Ann. Zootech. (Paris) 24:743-756.

Edwards, J. E., S. A. Huws, E. J. Kim, and A. H. Kingston-Smith. 2007. Characterization of the dynamics of initial bacterial colonization of nonconserved forage in the bovine rumen. FEMS Microbiol. Ecol. 62:323-335.

Faisant, N., V. Planchot, F. Kozlowski, M. P. Pacouret, P. Colonna, and M. Champ. 1995. Resistant starch determination adapted to products containing high levels of resistant starch. Sci. Aliments 15:83-89.

Fanchone, A., P. Noziere, J. Portelli, B. Duriot, V. Largeau, and M. Doreau. 2013. Effects of nitrogen underfeeding and energy source on nitrogen ruminal metabolism, digestion, and nitrogen partitioning in dairy cows. J. Anim. Sci. 91:895-906.

Gado, H. M., A. Z. M. Salem, P. H. Robinson, and M. Hassan. 2009. Influence of exogenous enzymes on nutrient digestibility, extent of ruminal fermentation as well as milk production and composition in dairy cows. Anim. Feed Sci. Technol. 154:36-46.

Gencoglu, H., R. D. Shaver, W. Steinberg, J. Ensink, L. F. Ferraretto, S. J. Bertics, J. C. Lopes, and M. S. Akins. 2010. Effect of feeding a reduced-starch diet with or without amylase addition on lactation performance in dairy cows. J. Dairy Sci. 93:723-732.

Hart, S. P., and C. E. Polan. 1984. Effect of sodium bicarbonate and disodium phosphate on animal performance, ruminal metabolism, digestion, and rate of passage in ruminating calves. J. Dairy Sci. $67: 2356-2368$

Hristov, A. N., C. E. Basel, A. Melgar, A. E. Foley, J. K. Ropp, C. W. Hunt, and J. M. Tricarico. 2008. Effect of exogenous polysaccharide-degrading enzyme preparations on ruminal fermentation and digestibility of nutrients in dairy cows. Anim. Feed Sci. Technol. 145:182-193.

Huntington, G. B. 1997. Starch utilization by ruminants: From basics to the bunk. J. Anim. Sci. 75:852-867.

INRA. 2007. Nutrition of Cattle, Sheep and Goats: Animal NeedsFeed Values. Quae Editions, Paris, France.

Jung, S., and K. Vogel. 2008. Determination of Ronozyme RumiStar alpha-amylase activity in feed and per se samples. Regula- tory Report No 2500706. DSM Nutritional Products Ltd., Basel, Switzerland.

Klingerman, C. M., W. Hu, E. E. McDonell, M. C. DerBedrosian, and L. Kung Jr. 2009. An evaluation of exogenous enzymes with amylolytic activity for dairy cows. J. Dairy Sci. 92:1050-1059.

Lettat, A., P. Noziere, M. Silberberg, D. Morgavi, C. Berger, and C. Martin. 2012. Rumen microbial and fermentation characteristics are affected differently by bacterial probiotic supplementation during induced lactic and subacute acidosis in sheep. BMC Microbiol. $12: 142$.

Martin, C., B. Michalet-Doreau, G. Fonty, and A. Williams. 1993 Postprandial variations in the activity of polysaccharide-degrading enzymes of fluid- and particle-associated ruminal microbial populations. Curr. Microbiol. 27:223-228.

McCarthy, M. M., M. A. Engstrom, E. Azem, and T. F. Gressley. 2013. The effect of an exogenous amylase on performance and total-tract digestibility in lactating dairy cows fed a high-byproduct diet. J. Dairy Sci. 96:3075-3084.

Morgavi, D. P., H. Boudra, J. P. Jouany, and D. Graviou. 2003. Prevention of patulin toxicity on rumen microbial fermentation by $\mathrm{SH}-$ containing reducing agents. J. Agric. Food Chem. 51:6906-6910.

Nozière, P., I. Ortigues-Marty, C. Loncke, and D. Sauvant. 2010. Carbohydrate quantitative digestion and absorption in ruminants: From feed starch and fibre to nutrients available for tissues. Animal 4:1057-1074.

Offner, A., and D. Sauvant. 2004. Prediction of in vivo starch digestion in cattle from in situ data. Anim. Feed Sci. Technol. 111:41-56.

Owens, F. N., and C. F. Hanson. 1992. External and internal markers for appraising site and extent of digestion in ruminants. J. Dairy Sci. 75:2605-2617.

Potts, T. J. 1967. Colorimetric determination of urea in feeds (Report of AOAC Committee). J. AOAC 50:56-58.

Sadet, S., C. Martin, B. Meunier, and D. P. Morgavi. 2007. PCR-DGGE analysis reveals a distinct diversity in the bacterial population attached to the rumen epithelium. Animal 1:939-944.

Sauvant, D., and J. Van Milgen. 1995. Dynamics aspects of carbohydrate and protein breakdown and the associated microbial matter synthesis. Pages 71-91 in Proc. Ruminant Physiology: Digestion, Metabolism, Growth and Reproduction; Proc. 8th Int. Symp. Rumin. Physiol. Ferdinand Enke Verlag, Stuttgart, Germany.

Siddons, R. C., J. Paradine, D. E. Beever, and P. R. Cornell. 1985. Ytterbium acetate as a particulate-phase digesta-flow marker. Br. J. Nutr. 54:509-519.

Stevenson, D. M., and P. J. Weimer. 2007. Dominance of Prevotella and low abundance of classical ruminal bacterial species in the bovine rumen revealed by relative quantification real-time PCR. Appl. Microbiol. Biotechnol. 75:165-174.

Van Soest, P. J., J. B. Robertson, and B. A. Lewis. 1991. Methods for dietary fiber, neutral detergent fiber, and nonstarch polysaccharides in relation to animal production. J. Dairy Sci. 74:3583-3597.

Weatherburn, M. W. 1967. Phenol-hypochlorite reaction for determination of ammonia. Anal. Chem. 39:971-974.

Weiss, W. P., W. Steinberg, and M. A. Engstrom. 2011. Milk production and nutrient digestibility by dairy cows when fed exogenous amylase with coarsely ground dry corn. J. Dairy Sci. 94:24922499.

Yu, Z., and M. Morrison. 2004. Improved extraction of PCR-quality community DNA from digesta and fecal samples. Biotechniques $36: 808-812$. 